

\section{DISCLAIMER}

This report was prepared as an account of work sponsored by an agency of the United States Government. Neither the United States Government nor any agency Thereof, nor any of their employees, makes any warranty, express or implied, or assumes any legal liability or responsibility for the accuracy, completeness, or usefulness of any information, apparatus, product, or process disclosed, or represents that its use would not infringe privately owned rights. Reference herein to any specific commercial product, process, or service by trade name, trademark, manufacturer, or otherwise does not necessarily constitute or imply its endorsement, recommendation, or favoring by the United States Government or any agency thereof. The views and opinions of authors expressed herein do not necessarily state or reflect those of the United States Government or any agency thereof. 


\section{DISCLAIMER}

Portions of this document may be illegible in electronic image products. Images are produced from the best available original document. 


\title{
LPTR IRRADIATION OF UNIVERSITY OF PENNSYLVANIA
}

\author{
METGLAS SAMPLES \\ Unclassified \\ January 15,1976 \\ Susan C. MacLean and Curtis L. Rowe
}

Dr. T. Egami of the University of Pennsylvania requested irradiation of two types of alloys, designated MetGlas \#2826 and \#2826B, in the Livermore Pool Type Reactor (LPTR).

The LPTR is a 3 MW heterogeneous tank-type pool research reactor. It is light water moderated and cooled, beryllium reflected. It has MTRtype fuel elements, composed of aluminum and enriched uranium.

The MetGlas samples and an iron dosimetry foil were packaged (Fig. 1) and irradiated in position E-1 of the reactor core. This position is located at the northwest edge of the core, in the beryllium reflector. The neutron spectrum is, therefore, moderated to a greater degree than in the center of the core. The spectrum has been evaluated by Richard V. Griffith of LLL, using multiple foil activation and iterative computer fitting (UCRL-50007-74-2). The spectrum in the absence of cadmium can be summarized as follows:

$\begin{array}{ll}\text { Neutron Energy } & \text { Flux }\left(\mathrm{n} / \mathrm{cm}^{2}-\mathrm{sec}\right) \\ <0.54 \mathrm{eV} & 3.39 \times 10^{13} \\ 0.54 \mathrm{eV} \text { to } 0.1 \mathrm{MeV} & 1.04 \times 10^{13} \\ 0.1 \mathrm{MeV} \text { to } 1.0 \mathrm{MeV} & 8.05 \times 10^{12} \\ >1.0 \mathrm{MeV} & 3.95 \times 10^{12}\end{array}$

Five flat wire samples each of MetGlas \#2826 and \#2826B were prepared for irradiation. MetGlas \#2826 samples measured $42 \mathrm{~mm}$ in length and $1.4 \mathrm{~mm}$ 
in width. The MetGlas \#2826B samples were also $42 \mathrm{~mm}$ long but were 0.8 $\mathrm{mm}$ wide. The composition of the two alloys was as follows:

$\frac{\text { MetGlas \#2826 }}{(\text { at. } \%)} \quad \frac{\text { MetGlas 2826B }}{(\text { at. } \%)}$

$\begin{array}{lrr}\text { Nickel } & 40 & 49 \\ \text { Iron } & 40 & 29 \\ \text { Phosphorus } & 14 & 14 \\ \text { Boron } & 6 & 6 \\ \text { Silicon } & - & 2\end{array}$

The reactor water temperature is $40^{\circ} \mathrm{C}$ and the sample temperature was estimated to be less than $100^{\circ} \mathrm{C}$. The irradiation was carried out by the LLL Radiochemistry Division LPTR operating staff for 5000 minutes during the period July 15, 1975 to August 1, 1975. The reactor power was monitored continuously by ionization chambers and particularly by the heat balance across the core. The power was controlled at $3 \mathrm{MW} \pm 5 \%$. The irradiation schedule was as follows:

Date (1975)

July 15

July 1.6

July 17

July 18

July 22

July 23

July 24

July 25

July 29

July 30

July 31

August 1

\section{Length of Irradiation}

7 hours 6 minutes

6 hours 17 minutes

7 hours 28 minutes

7 hours 49 minutes

5 hours 47 minutes

7 hours 26 minutes

7 hours 47 minutes

7 hours 54 minutes

6 hours 46 minutes

6 hours 39 minutes

6 hours 57 minutes

5 hours 25 minutes 
Following the irradiation, and due to the activity of the specimens, the sample can was stored for one month before opening. The MetGlas samples were returned to Dr. Egami at the University of Pennsylvania. The iron dosimetry foil was delivered to Ruth N. Anderson in the LLL Radiochemistry Division. She carried out the gamma ray counting. A $1.57 \mathrm{~mm}$ thick cadmium absorber was required over the sample during the counting.

The ${ }^{54} \mathrm{Fe}(n, p){ }^{54} \mathrm{Mn}$ reaction in iron was used for the dosimetry measurements. The average fluence on the iron dosimetry foil was calculated using the method described in UCRL-51393, Rev. 1. The values used in the calculations were as follows:

Iron sample density $-7.9 \mathrm{gm} / \mathrm{cm}^{3}$

${ }^{54}$ Mn half-life - 31,2.3 days

Iron atomic mass - $55.847 \mathrm{amu}$

${ }^{54} \mathrm{Fe}$ isotopic abundance $-5.82 \%$

Yield of $835 \mathrm{KeV}$ gamma ray - $100 \%$

$t_{0}$ was taken as the end of the irradiation period. Corrections were made for decay assuming a constant flux during the total time the sample can was in the reactor, including periods of no power. This introduces a neglible error because of the long half-life of ${ }^{54} \mathrm{Mn}$.

The following spectrum - averaged cross sectionswere used:

$$
\begin{array}{ll}
E>0.1 \mathrm{MeV} & 0.0283 \text { barn } \\
E>1.0 \mathrm{MeV} & 0.0848 \text { barn }
\end{array}
$$

These are based upon the spectrum measurements of Griffith and upon ${ }^{54} \mathrm{Fe}$ cross section data from the Livermore Evaluated Nuclear Cross Secion Library (UCRL-50400, Vo1.4, 1971). 
The results were as follows:

$$
\begin{aligned}
& \text { Dosimetry Foil } \\
& \text { Fe-D-111 } \\
& \text { The estimated overall uncertainty of these results is } \pm 30 \% \text {. The } \\
& \text { values given here represent average fluences over the volume of the } \\
& \text { dosimetry foil. The fluences on the MetGlas samples are expected to } \\
& \text { correspond closely to these values because of the proximity of the samples } \\
& \text { and foil and the volume nature of the neutron source. }
\end{aligned}
$$



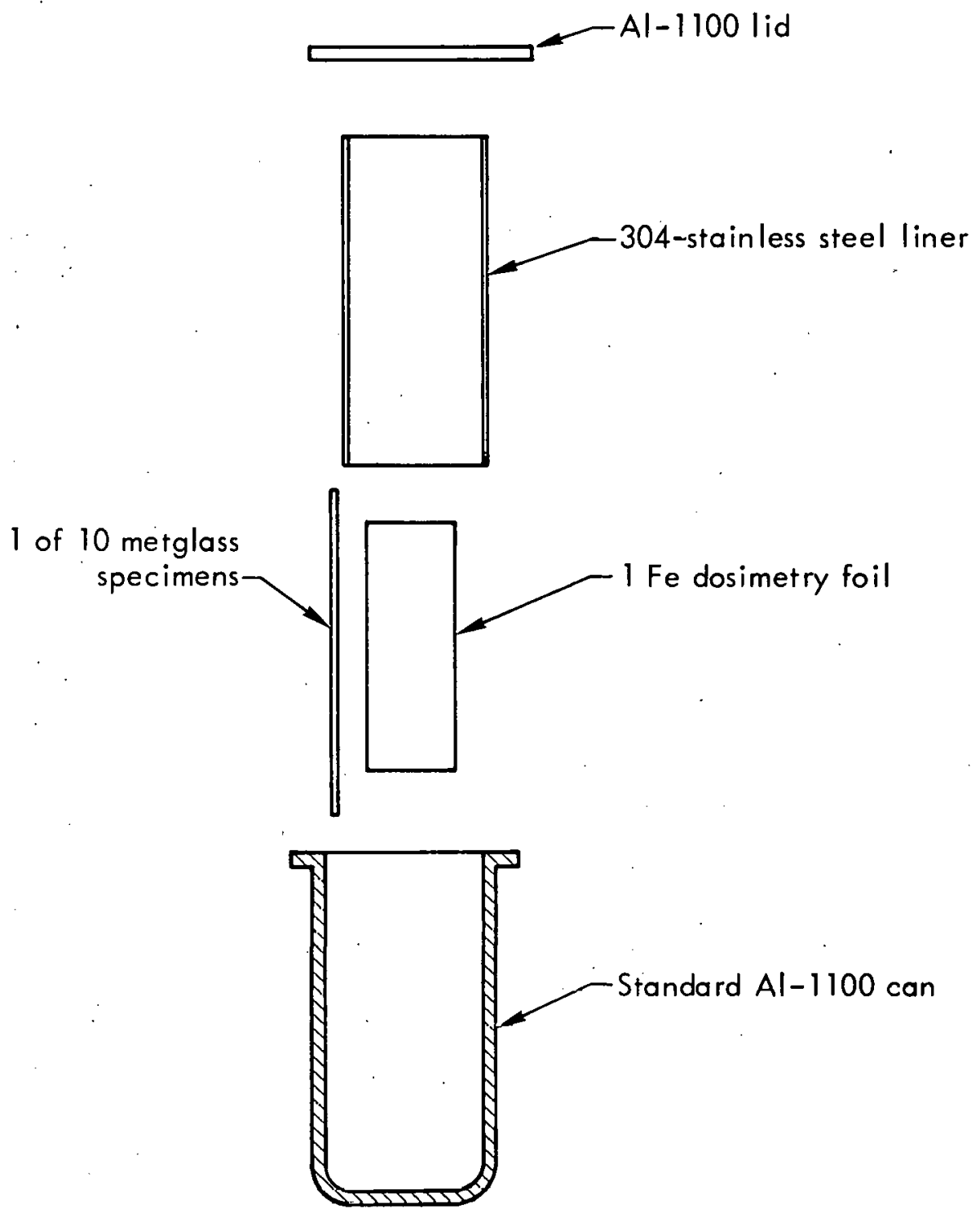
$A C K N O W L E D G M E N T S$

The authors are grateful to

Dr. Richard Van Konynenburg

for his support and encouragement. 
INTERNAL DISTRIBUTION

R. N. Anderson, $L-237$

R. J. Borg, L-231

C. Cline, L-503

J. W. Frazer, L-401

C. Gatrousis, $L-231$

M. W. Guinan, L-233

J. Y. Leong, L-540

L. G. Mann, L-540

J. B. Mitche $11, L-426$

W. J. Richards, $L-540$

L. W. Roberts, L-401

C. L. Rowe, L-540

R. R. Vandervoort, L-426

R. A. Van Konynenburg, L-233

C. E. Violet; $L-540$

S. C. MacLean L-233

TID, L-9 (15)

\section{EXTERNAL DISTRIBUTION}

Dr. T. Egami

University of Pennsylvania Philadelphia, Penn. 19174

Dr. Louis Ianniello, USERDA Division of Physical Research Washington, D. C. 20545
EXTERNAL DISTRIBUTION (cont.)

Dr. Donald Stevens, USERDA

Division of Physical Research

Washington, D. C. 20545

Dr. Mark Wittels, USERDA

Division of Physical Research Washington, D. C. 20545

TIC, Oak Ridge, TN, (27)

\section{NOTICE}

"This report was prepared as an account of work sponsored by the United States Government. Neither the United States nor the United Stutes Energy Research \& Development Administration, nor any of their employees, nor any of their contractors. subcontractors, or their employees, makes any warranty, express or implied, or assumes any legal liability or responsibility for the accuracy, conpleteness or usefulness of any information, apparatus, product or process disclosed, or represents that its use would not infringe privately-owned rights."

Printed in the United States of America Available from

National Technical Information Service

U.S. Department of Commerce 5285 Port Royal Road

Springfield, Virginia 22151

Price: Printed Copy \$_* ${ }_{*}$; Microfiche $\$ 2.25$
NTIS

Selling Price

$\$ 4.00$

$\$ 5.45$

$\$ 7.60$

$\$ 10.60$

$\$ 13.60$ 
Technical Information Department LAWRENCE LIVERMORE LABORATORY

Un versity of California | Livermore, California | 94550 